\title{
Neonatal screening for glucose-6-phosphate dehydrogenase deficiency: sex distribution
}

\author{
Michael Kaplan, Cathy Hammerman, Rivka Kvit, Bernard Rudensky, Ayala Abramov
}

\begin{abstract}
Eight hundred and six newborn infants at high risk for glucose-6-phosphate dehydrogenase (G-6-PD) deficiency were screened; $30 \cdot 2 \%$ of the boys and $10 \cdot 4 \%$ of the girls had severe G-6-PD deficiency. Surprisingly, $14 \%$ of the enzyme deficient girls had a father from a low risk ethnic group. Girls of high risk mothers should be screened for G-6-PD deficiency regardless of paternal origin.

(Arch Dis Child 1994; 71: F59-F60)
\end{abstract}

Glucose-6-phosphate dehydrogenase $\mathrm{e}^{\text {Mediterranean }}$ (G-6-PD) deficiency is known to be associated with neonatal jaundice and even kernicterus. ${ }^{1-3}$ Neonatal screening programmes are therefore important in high risk groups to predict those likely to develop hyperbilirubinaemia. Being an $\mathrm{X}$ linked genetic condition the prevalence of G-6-PD deficiency in any given population is determined by the number of deficient males and, as a result, many population surveys and clinical studies have related to males only. ${ }^{4}$ However, female enzyme deficient infants are no less at risk for jaundice than their male counterparts. ${ }^{2}$ As the prevalence in high risk female Sephardic Jews (Oriental origin) is by and large unknown, we screened these neonates to determine the prevalence of severe G-6-PD deficiency in both sexes.

\section{Subjects and methods}

Included in this survey are newborn boys and girls whose Sephardic Jewish mothers' families had a clear lineage and originated in areas of Asia Minor including Kurdistan, Iraq, Turkey, Iran, Syria, Lebanon, and Buchara. These population groups are known to be at high risk for G-6-PD deficiency. ${ }^{4}$ Paternal lineage was not taken into consideration as an indication for screening.

Heelstick blood specimens were taken within 48 hours of delivery and studied by a dye reduction method using a commercial kit (the visual qualitative determination of
G-6-PD deficiency in red cells (No 400), Sigma Chemical Company). This qualitative test identifies those with very low, but not intermediate, levels of enzymatic activity - that is, hemizygous males, female homozygotes, and some female heterozygotes with unequal lyonisation.

The number of G-6-PD deficient newborn boys and girls was determined and the predicted incidence in females calculated according to the Hardy-Weinberg equilibrium. ${ }^{5}$ The latter was compared with the actual incidence using $\chi^{2}$ analysis. Affected girls were analysed in relation to their parental marriage patterns.

\section{Results}

Between May 1989 and December 1992, 806 high risk neonates were studied. Overall, 127 $(30 \cdot 2 \%)$ of 420 boys and $40(10 \cdot 4 \%)$ of 386 girls were G-6-PD deficient. The predicted number of affected girls was $35(9 \cdot 1 \%)$ and was close to the actual figure $(p=0.58)$. Details of the various subgroups tested are shown in table 1.

Information regarding geographic origin of both parents was available for 330 couples and for 28 of the G-6-PD deficient girls. These were divided into three groups as shown in table 2. As expected, G-6-PD deficient girls were more common when both parents were of high risk groups, but surprisingly, $14 \%$ of the affected girls had low risk fathers.

\section{Discussion}

The aim of our screening programme was to diagnose those infants with G-6-PD deficiency early in neonatal life in order to predict those at risk for developing jaundice, to prevent early discharge of these infants, and to warn the parents of the dangers of being enzyme deficient. The screening test we employed was chosen for its simplicity and brevity which lent itself to achieving our goal. Sophisticated technical expertise or equipment is unnecessary and the test can easily be

Table 1 Results of screening for G-6-PD deficiency in boys and girls of the various subgroups tested. The subgroups were determined by the mothers' families' geographic area of origin

\begin{tabular}{llllllll}
\hline & Total & Kurdistan & Iraq & Syria & Iran & Turkey & Buchara \\
\hline Boys & & & & & & & \\
$\quad$ No screened & 420 & 84 & 111 & 48 & 133 & 25 & 19 \\
$\quad$ No (\%) G-6-PD deficient & $127(30 \cdot 2)$ & $49(58 \cdot 3)$ & $36(32 \cdot 4)$ & $13(27 \cdot 1)$ & $15(11 \cdot 3)$ & $12(48 \cdot 0)$ & $2(10 \cdot 5)$ \\
Girls & 386 & 76 & 96 & 56 & 117 & 30 & 11 \\
$\quad$ No screened & $40(10 \cdot 4)$ & $18(23 \cdot 7)$ & $9(9 \cdot 4)$ & $5(8 \cdot 9)$ & $6(5 \cdot 1)$ & $1(3 \cdot 3)$ & $1(9 \cdot 1)$ \\
$\quad$ No (\%) G-6-PD deficient & $35(9 \cdot 1)$ & $26(34)$ & $10(10 \cdot 5)$ & $4(7 \cdot 3)$ & $1(1 \cdot 3)$ & $7(23)$ & $0 \cdot 1(1 \cdot 1)$ \\
No (\%) predicted G-6-PD deficient \\
$\begin{array}{l}\text { Predicted } v \text { actual G-6-PD deficient } \\
\text { (p value) }\end{array}$ & 0.58 & 0.21 & 1.0 & 1.0 & 0.13 & 0.06 & 0.92 \\
\hline
\end{tabular}


Table 2 Relationship of G-6-PD deficiency in newborn girls to parental marriage patterns

\begin{tabular}{lll}
\hline $\begin{array}{l}\text { Parental marriage } \\
\text { partners }\end{array}$ & $\begin{array}{l}\text { \% Of population } \\
(n=330 \text { couples })\end{array}$ & $\begin{array}{l}\text { \% Of G-6-PD deficient } \\
\text { girls ( } n=28)\end{array}$ \\
\hline (A) Identical high risk group & 35.4 & 53.6 \\
(B) Non-identical high risk group & 23.3 & 32.1 \\
(C) High risk mother/low risk father & 41.3 & 14.3 \\
\hline
\end{tabular}

performed in rural hospitals. Of more concern than the genetic classification of females into normals, hemizygotes, and homozygotes was the determination of the amount of functioning enzyme. Most likely female hemizygotes with a normal screening test will have sufficient enzyme activity to prevent their suffering from the consequences of G-6-PD deficiency in the neonatal period and vice versa, and therefore a more complicated and time consuming test was deemed unnecessary for our purposes.

As G-6-PD deficiency is an $\mathrm{X}$ linked condition, it is sufficient to establish the maternal origin only to determine the lineage in males. In females, both paternal and maternal ancestries should theoretically be determined. However, as some females can be deficient with a normal father, we screened infants based on the maternal geographic origin alone. After the establishment of the State of Israel, and the return of many Jewish exiles, there has been much intermarriage between the various population subgroups. Most likely, the original population groups, preserved virtually intact for over two millennia, had higher female prevalence of the deficiency. This study in no way attempts to assess these figures nor to supply data regarding gene frequency. It does, however, provide information regarding screening of high risk infants for the prediction of those more likely to develop hyperbilirubinaemia.

The classic study of Sheba et al of the many subgroups of the Israeli population, performed in the early years of the State and before intermarriage could have had an effect, studied the prevalence of G-6-PD deficiency in adult males only. ${ }^{4}$ The only study of Israeli females of which we are aware is that of Cohen, performed several decades ago, in which she found that $45 \%$ of newborn girls, where both parents originated in Kurdistan, had G-6-PD deficiency. ${ }^{6}$ Intermarriage between the groups probably explains the lower rate we found in girls of Kurdistani origin. Worldwide, the prevalence of G-6-PD deficiency in females has also been infrequently studied.

It is of special interest that $14 \%$ of G-6-PD deficient infant girls were found to be in category $C$. In this group the incidence of G-6-PD deficiency in females would be expected to be low. Unequal lyonisation probably accounts for many of these infants. According to the Lyon hypothesis, one of the two $\mathrm{X}$ chromosomes in each cell is randomly inactivated, and thus the female is a mosaic of $50 \%$ maternally derived $\mathrm{X}$ chromosome genes, and $50 \%$ paternal. There will thus be two populations of erythrocytes: one normal for G-6-PD, the other deficient. Non-random lyonisation may lead to a high proportion of G-6-PD deficient cells in any given female.

Based on our findings, we recommend that screening programmes of high risk populations for the prediction of G-6-PD associated neonatal hyperbilirubinaemia should include both infant boys and girls, regardless of paternal origin.

1 Beutler E. Glucose-6-phosphate dehydrogenase deficiency. N Engl f Med 1991; 324: 169-74.

2 Kaplan M, Abramov A. Neonatal hyperbilirubinemia associated with glucose-6-phosphate dehydrogenase deficiency in Sephardic-Jewish neonates: incidence, severity and the effect of phototherapy. Pediatrics 1992; 90: 401-5.

3 Doxiadis SA, Valaes T. The clinical picture of glucose6-phosphate dehydrogenase deficiency in early infancy. Arch Dis Child 1964; 39: 545-55.

4 Sheba C, Szeinberg A, Ramot B, Adam A, Ashkenazi I. Epidemiologic surveys of deleterious genes in different population groups in Israel. Am $\mathcal{F}$ Public Health 1962; 52: population.

5 Piomelli $S$. G6PD deficiency and related disorders of the pentose pathway. In: Nathan DG, Oski FA, eds. Hematology of infancy and childhood. 3rd Ed. Philadelphia WB Saunders, 1987: 558

6 Cohen T. Genetic markers in migrants to Israel. Isr f Med Sci $1971 ; 7: 1509-14$ 